Portland State University

PDXScholar

2016

\title{
Characterizing Agile Supply Partnerships in the Fashion Industry
}

\author{
Corrado Cerruti \\ University of Rome Tor Vergata \\ Carlos Mena \\ Portland State University \\ Heather Skipworth \\ Cranfield University \\ Ernesto Tavoletti \\ University of Macerata
}

Follow this and additional works at: https://pdxscholar.library.pdx.edu/busadmin_fac

Part of the Fashion Business Commons, and the Operations and Supply Chain Management

Commons

Let us know how access to this document benefits you.

\section{Citation Details}

Cerruti, C., Mena, C., Skipworth, H., \& Tavoletti, E. (2016). Characterizing agile supply partnerships in the fashion industry. International Journal of Operations \& Production Management, 36(8), 923-947.

This Post-Print is brought to you for free and open access. It has been accepted for inclusion in Business Faculty Publications and Presentations by an authorized administrator of PDXScholar. Please contact us if we can make this document more accessible: pdxscholar@pdx.edu. 


\section{Characterizing Agile Supply Partnerships in the Fashion}

\section{Industry}

\section{Introduction}

The concept of supply chain agility is centred on mastering uncertainty and change in markets characterized by high volatility, intense competition, and changing customer requirements (Goldman et al., 1995; Van Hoek et al., 2001; Zhang, 2011) - conditions that prevail in the fashion industry (Christopher et al., 2004; Masson et al., 2007). In an agile supply chain strategy, suppliers play a central role as they allow firms to access new resources to improve their performance in terms of responsiveness and time-tomarket (Christopher, 2000; Swafford et al., 2006; Tavani et al., 2014). For this reason, partnerships are often presented as a pillar of agility (Christopher, 2000; Zhang and Sharifi, 2000). In the fashion industry, such supply partnerships are particularly important, given that most fashion companies have limited in-house capabilities and rely heavily on their supply network (Tran, 2010).

Despite the general consensus on the relevance of partnerships to supply chain agility, the literature reveals disagreements and contradictions regarding the specific role and characteristics of supply relationships in an agile strategy. Some authors propose longterm partnerships (Yusuf et al., 2004; Storey et al., 2005; Zhang, 2011), while others recommend short-term relationships, as current suppliers might not have the required skills and capabilities to deliver future strategies (Goldman et al., 1995; Gunasekaran, 1998; Van Hoek et al., 2001; Christopher et al., 2004). 
Given such contradictory theoretical positions, this paper investigates how fashion firms leverage on supply relationships to deliver their strategies using three in-depth case studies of Italian footwear manufacturers. In doing so, the study aims to explore the conditions and characteristics that support the development of agile supply partnerships (ASPs), which we define as high-involvement, short-term supply relationships.

The context of the research is the Macerata-Fermo district, the largest footwear district in Italy, including more than 1,700 companies in the footwear industry with more than 22,200 employees (Assocalzaturifici, 2014).

The remainder of the paper is structured as follows: section two presents the debate on the characteristics of supply partnerships in agile supply chains; section three describes the methodology used for the research; sections four to six analyze the evidence from the three case studies, report the perspective of the suppliers in three key supply categories and present a cross-case analysis, discussing the paradox of ASPs. Conclusions, limitations and implications for future research are presented in the final section.

\section{Literature review}

\subsection{The concept of agility in the fashion industry}

Fashions can be defined as "temporary cyclical phenomena that are adopted by consumers for a particular time and situation" (Sproles, 1981, p. 116) and "the very survival of fashion industry depends on regular style changes." (p. 118). Agility has been proposed as " $a$ comprehensive response to the challenges posed by a business environment dominated by change and uncertainty" (Goldman et al., 1995, p. 
3). Indeed it is an approach applicable to markets/products characterized by a fast pace of change in terms of market volatility, intense competition, changes in customer requirements, accelerating technological change, and change in social factors (Christopher, 2000; van Hoek et al., 2001; Yusuf et al., 2004; Masson et al., 2007, Gligor, 2014) - factors that characterize the fashion industry. The agile approach can be both reactive and proactive, as Zhang and Sharifi (2000, p. 496) remark, "the concept of agility comprises two main factors: (1) responding to changes (anticipated or unexpected) in proper ways and due time; (2) exploiting changes and taking advantage of changes as opportunities".

Agility helps fashion companies to face short-life cycles, high volatility and low predictability (Christopher et al., 2004; Masson et al., 2007). Such agility has to be managed across the supply chain, considering that most fashion companies have only limited in-house capabilities and their agility relies heavily on the agility of their wide supply network (Tran, 2010).

In the fashion industry, agility is mainly linked to a high collection renewal rate. The decision to modify, to a large extent, the collections every season involves radical changes in the products, often with significant impacts on the supply network due to major changes in the processes and materials used (Tran, 2010). Moreover, a major change in the collection proposed is very challenging for production planning, as the fine-tuning of the new models (and eventually of the new suppliers) is carried out under severe time pressure during the season collection production period between the fashion fairs and the selling period. 
Some authors argue that not all components of a product require the same type of agility. Baramichai et al. (2007) distinguish among different types of agility, on the basis of different supply market conditions and purchasing strategies, and Drake et al. (2013), propose a portfolio model selecting lean and/or agile approaches based on the characteristics of the items being sourced. For this research, we adopt this idea of categorizing suppliers according to their impact on the fashion trends, as these imply different agility challenges.

\subsection{Supply partnerships in agile supply chains}

A high level of collaboration and integration with suppliers is considered an important enabler of agile supply chains (Christopher, 2000; Gligor and Holcomb, 2012; Mena et al., 2007). This type of highly involved relationship is frequently referred to as a supply partnership, which has been described as a relationship between a firm and its supplier "based on mutual dependency and trust, where both parties are committed to collaboration beyond a sequence of buying-selling transactions" (Ploetner and Ehret, 2006, p. 4).

High-involvement relationships can be defined as supply partnerships where the two parties plan and coordinate their activities relying on each other resources and capabilities (Ford et al., 2011). This type of relationships are characterized by one or more of the following aspects: 1) inter-firm knowledge sharing routines; 2) investment in relationship-specific assets; and 3) self-enforcement governance mechanisms (Dyer and Singh, 1998). Inter-firm knowledge sharing routines can be defined as "institutionalized inter-firm processes that are purposefully designed to facilitate knowledge exchanges between partners" (Dyer and Singh, 1998, p. 665). Investment in relationship-specific assets can be defined as "durable investments [e.g. in site, physical 
and human assets] that are undertaken in support of particular transactions" (Williamson, 1985, p. 55). Self-enforcement governance mechanisms relate mainly to trust, and other informal relational aspects, that can help minimize transaction costs and ensure the continuity and stability of the relationship (Zaheer and Venkatraman, 1995).

While there is a general consensus on the relevance of partnerships to supply chain agility, the literature reveals disagreements and contradictions regarding the duration of supply relationships in an agile strategy. Some authors propose long-term partnerships with a reduced number of trustworthy suppliers as enablers of supply chain agility. According to this view, reciprocal commitment and trust are considered important to face the challenges and time-pressures characterizing the agile strategy (Yusuf et al., 2004; Storey et al., 2005; Drake et al., 2013; Narayanan et al., 2015).

An alternative argument stresses that, given the context of change and uncertainty characterizing an agile strategy, current suppliers might not have the required skills or availability in the future and therefore short-term collaborations are preferable (Goldman et al., 1995; Gunasekaran, 1998; Christopher et al., 2004). Other authors highlight that both long-term and short-term supply partnerships can fit into an agile strategy, depending on different market/product characteristics (Yusuf et al., 1999; Baramichai et al., 2007; Zhang, 2011). In any case, the definition of short- and longterm relationships is contingent upon the pace of evolution in an industry. Hence, the concept of clockspeed, defined as the pace of evolution of products, processes and organizations in an industry (Fine, 1998), provides a useful reference to discriminate short- and long-term relationships across different industries. 
The literature on partnerships stresses the importance of a long time frame to establish high-involvement collaboration. Typically it is assumed that partnerships are long-term and high-involvement, making ASPs appear as a paradox, given the time and effort required to develop them (Mesquita and Brush, 2008). Similarly, Dyer and Nobeoka (2000) stress that the development of high-performance knowledge sharing networks require strong commitment and significant resources over many years. Moreover, the literature on partnerships also highlights the potential losses derived from abandoning established high-involvement relationships, given that this action might involve losing many relational capabilities and practices developed in repeated interactions that cannot be easily transferred to different relationships (Mesquita and Brush, 2008).

Partnerships established for the short-term might appear as a paradox, given the time and effort required to develop them, and facing such an apparent paradox is an important step in understanding supply relationships in agile supply chains. Furthermore, since agility is a relatively new concept, the practices that support an agile supply chain are only now starting to be defined; for instance Christopher and Holweg (2011) present seven actions for agility. While these are strategically useful, they are at a high level, for instance dual sourcing, asset sharing and outsourcing, and do not specify the conditions under which they should be applied. This oversight is particularly emphatic in the case of supply relationships, where "[a] lack of consensus exists on supplier involvement (SI) and its impacts on product development, innovation process and performance, and company capabilities" (Tavani et al., 2014, p. 66). This study aims to address this gap, highlighting the conditions for, and characteristics of, ASPs. 


\section{Research Methodology}

In response to the evidence from the literature review, this research investigates agile supply partnerships (ASPs) in the fashion footwear industry focusing on the following questions:

Q1: What are the conditions for ASPs in the fashion footwear industry?

Q2: What are the characteristics of ASPs in the fashion footwear industry?

Given the gaps and contradictions related to "supply partnerships within an agile strategy", the state of prior research can be considered to be at a nascent stage. Hence, this investigation has been developed as an exploratory research project where the questions arise both from theory and practice. For this purpose a case study approach, using multiple embedded units of analysis, was followed (Yin, 2014). The remaining part of this section includes an overview of the context of the research and a description of each of the three steps of the research: (i) Define and design, (ii) Prepare and collect; and (iii) Analyze and conclude

\subsection{Context: The Macerata-Fermo Footwear District}

The context in which the research took place is the Macerata-Fermo district, the largest footwear district in Italy. The district is located in the Marche region, in the centre of Italy on the Adriatic coast, across the two provinces of Macerata and Fermo. In 2013 it included more than 1,700 companies involved in different roles in the footwear supply chain $(33 \%$ of the Italian companies active in the footwear industry) with more than 22,000 employees ( $28 \%$ of the overall employment in this industry in Italy) (Assocalzaturifici, 2014). One third of these companies are footwear companies 
developing and presenting their own collections, while the rest are components and accessories manufacturers or subcontractors.

For every fashion season, footwear companies bring to the market thousands of new models, with a development \& launch process based on two different stages: first the fashion fairs, when the footwear companies develop their prototypes with limited feedback from the market, and second the receipt of customer orders (Cerruti and Tavoletti, 2012). Before the fashion fairs, all the activities are characterized by high uncertainty and variability. During this period the companies tend not to make volume commitments to suppliers, as they are maintaining high product variety in order to be more attractive at the fashion fairs. After the fashion fairs, all the activities are characterized by the need to deliver specific orders, under strong time pressure. During this period the companies try to avoid missing delivery dates to the retailers as this can increase the probability of lost sales and product returns. At this stage, synchronising all the flows from the different sources and efficiently allocating production becomes critical.

\subsection{Define and Design}

This initial stage includes the selection of the cases, a preliminary round of interviews with industry experts and the design of the data collection protocol. Three footwear companies with similar agile strategies were selected to provide literal replication (Manas, Fabi and Cesare Pacotti). Three supply categories, differently impacted on by fashion, were selected to provide theoretical replication. These were internal leather, soles and external leather - one company for each of these categories was investigated. In each case the supply relationship was the unit of analysis. The overall research design, including the selected cases and supporting interviews, is depicted in Figure 1. 
The criterion for the case studies selection was the renewal rate of seasonal collections as this study focuses on "high-turbulence" agility. In collaboration with the local Industrial Associations, three leading companies with a high renewal rate were selected. Given the characteristics of the footwear industry and its clockspeed based on the fashion seasons (spring/summer and autumn/winter), we agreed with the local Industrial Associations to define short-term relationships as those lasting less than one year. This timeframe is consistent with the product clockspeed for footwear as defined by Fine (1998, p. 239).

In each case the supply relationships were evaluated with respect to three key supply categories with diverse impacts on the appearance of the footwear and the fashion trend:

- External leather, highly influential on the fashion look.

- Soles, moderately influential on the appearance of the product.

- Internal leather, not influential, as it is not generally visible.

To account for the dyadic nature of the supplier relationships, a leading supplier for each of the supply categories was interviewed. This selection was made in collaboration with the local Industrial Association.

\subsection{Prepare and collect}

This stage involves data collection, which led to the preparation of three individual case reports. Data collection started with six meetings with the industry delegates of the 
footwear Industrial Associations of Macerata and Fermo, followed by a workshop with leading footwear entrepreneurs in the district. The interviews helped to define the competitive environment and the indicators of agile practice. The preliminary analysis was validated in a workshop organized by the two Industrial Associations (Cerruti and Tavoletti, 2012) and was the basis for the selection of the cases.

Three companies with high collection renewal rates were selected and the case studies were developed based on multiple data sources: informal meetings, two rounds of semistructured interviews (see Appendix A), balance sheets, accounting and purchasing data, as well as secondary data from the Industrial Associations. A final round of interviews was used to validate the information collected.

The data from the case studies were triangulated through a series of semi-structured interviews with the leading district suppliers in each supply category, as identified with the support of the Industrial Associations. For reason of confidentiality, none of the suppliers was asked to comment on their specific supply relationship with the three case companies. However, their comments regarding the challenges of establishing and managing supply relationships in the district apply to all three selected case companies. Interview details are reported in Appendix B including the companies, roles of the key informants, number of meetings and their total duration.

Interviews, which were carried out in Italian, were recorded and transcribed by a professional service provider. The transcriptions in Italian were used for the data analysis and draft reports. Once the companies validated the case reports, they were translated into English. 


\subsection{Analyze and conclude}

This step involved within-case analysis and cross-case pattern search (Eisenhardt, 1989) as well as the definition of the research contribution to theory and practice. The case studies have been designed as multiple embedded cases where, within each fashion company, different supply categories are analyzed.

Analysis of interview data used a coding based on the operationalization of the key variables of this research. The coding of the initial interviews was based on a broad classification of supply relationships taking into account the variables related to the degree of involvement, as discussed in the literature review (namely information sharing, investment sharing, and trust-based governance mechanisms), as well as to the duration (namely length and stability of the supply relationship). The following interviews added more granularity by taking into consideration the different supply categories. Each individual case study report was enriched with data from the company balance sheet and was reviewed by the informants who validated its content. The crosscase analysis was conducted using tables across different supply categories and agility profiles, as recommended by Miles and Huberman (1994).

\subsection{Quality criteria}

Four criteria are used to judge the quality of case study research, namely: construct validity, internal validity, external validity, and reliability (Yin, 2014). Table 1 defines each criterion and details the actions taken to ensure the quality of the research.

TABLE 1 AROUND HERE 


\section{Within Case Analysis}

The three case study companies - Manas, Fabi and Cesare Paciotti - are footwear companies from the Macerata-Fermo district that have a similar approach to agility. They all have high collection renewal rates (over 90\%), indicating they face "highturbulence" agility. They all maintain sampling and production processes nearby to allow high levels of responsiveness to fashion trends. They all postpone a very large share of leather purchasing, and the issuing of production orders, until after the fashion fair to allow alignment of the production stage with the emerging fashion trends. This approach to the collection development, and launch, highlights the high contribution to agility from the supply network, making supply relationships a critical element of their agile strategy.

An overview of agility performance indicators for all three companies is reported in Table 2. This is followed by a more detailed description of the three cases.

TABLE 2 AROUND HERE

\subsection{Manas}

Manas involves key suppliers in the development of new models and, in general, each supplier receives a full order for the articles they've been involved in designing and prototyping. At the same time, Manas assesses the performance of each supplier in terms of quality and delivery. In the case of operational underperformance, they identify 
alternative suppliers and allocate part of the production to them. On average about $20 \%$ of the suppliers, mainly external leather suppliers, are considered not to be fully reliable and therefore they are coupled with an alternative supplier. Even when suppliers underperform, the company prefers not to terminate the relationship immediately because all the suppliers are important for a fast ramp-up of the production process. At the same time, in fashion sensitive supply categories such as external leather, even suppliers with an excellent track record might not be involved in a given season as their components are considered not fashionable. Manas' approach towards partnerships has changed in the past few years due to the disruptive impact of a radically changed market scenario. "Ten years ago sourcing was much simpler, given that there were four or five materials, in three or four colors, and they lasted for two or three years. Today there are 20 or 30, even 35 materials, with a wide variety of colors".

Manas' approach to supply relationships is presented in Table 3. For external leather Manas relies on 20 different tanneries specializing in different types of leather. The relationship with them is highly involved, as indicated by the high level of inter-firm knowledge sharing and mainly self-enforced governance mechanisms; however, the relationships are predominantly short-term. Even when they have a wide vendor list, every year they look for new materials and suppliers. Relationships with suppliers of soles are also high-involvement; however, these partnerships tend to be long-term, because soles are less affected by fashion trends. Internal leather suppliers have a lowlevel involvement relationship with Manas, which is generally short-term due to reselection on the basis of costs and material availability. 
TABLE 3 AROUND HERE

\subsection{Fabi}

Fabi's strategy focuses on innovative designs, high quality materials and great attention to detail. This strategy influences the supplier selection and management. Supply partnerships are considered very important and are based mainly on knowledge sharing and on trust-based mechanisms. The company is positioned in the top range, and it offers a wide variety of models in low volumes, sometimes producing fewer than 10 pairs of a single model; suppliers tend to be niche contractors with a very high quality offer.

The CEO statement that "experience is the summation of all the mistakes done in the past!" represents a general inclination towards the development of long-term relationships. However, Fabi also looks for new ideas to renew its collection and therefore it requires innovative suppliers, which often means new suppliers, to influence and adopt fashion trends. To balance the pressures of stability and innovation Fabi has a very wide portfolio of qualified suppliers: almost 150 for external leather, 20 for internal leather and more than 10 for non-leather soles. On the basis of fashion trends, season after season Fabi chooses the best fitting suppliers. Some are selected every season, but others are involved only on a spot basis.

Fabi focuses on attention to detail and a desire to keep under their control as many processes as possible. This applies to all the production activities carried out internally (including the manufacturing of leather soles and some accessories) as well as to supplier management. Fabi's approach to supply relationships in the three supply categories are presented in Table 4. Every season Fabi aims to purchase the best 
external leather for its collection. Each tannery is highly specialized and is selected for giving the product a special look. Therefore, there are significant changes in external leather suppliers every season leading to short-term partnerships. Even in such an environment there are elements of stability, given that almost all of the selected suppliers are not completely new to the company, as they are likely to have supplied the company in the past and be prequalified. In any case, the identification of the best fit for the fashion trends takes priority over supply network stability.

TABLE 4 AROUND HERE

\subsection{Cesare Paciotti}

Cesare Paciotti has a very positive approach to supply partnerships, recognizing that its strength in the development of fashionable shoes is based, not only on its own creativity, but also on the contribution of its suppliers. "The supply network allows our footwear company to receive a wide array of proposals that are immediately available. When I need to reinvent a shoe, I have got 30 people bringing a component, to allow me to create a new shoe as I'm imagining it. We compete in a world where we work on a fashion proposal made up of 2,500 different samples, developed twice a year and then after every season we throw everything away".

The company balances two different pressures: the need for renewal and the importance of continuity in supply relationships. The need for renewal is related to fashion trends. The importance of continuity of relationships relates to the fact that over time the companies get to know each other, allowing them to be more effective. The importance of continuity is further supported by the need for secrecy in the development of new 
models. To balance these pressures, most of the suppliers are confirmed season after season; however, volumes depend on fashion trends.

Paciotti's approach to supply relationships in the three supply categories are presented in Table 5. Cesare Paciotti emphasizes the relevance of external leather because of its impact on the look of the shoes. Therefore Paciotti leverages on the different, and constantly changing, types of processing, colouring or finishing of the leather to impress the customer. Consequently, with the exception of a few evergreen items, every season the company radically revises the choice of the external leather, and therefore the suppliers that will be used. The company highlights that short-term partnerships are developed because fashion trends do not allow it to offer more stability; however most of them are recurring. Moreover, short-term relationships are not used deliberately, unless they are clearly related to non-recurring opportunities, such the case of shoes set with real diamonds.

\section{TABLE 5 AROUND HERE}

\section{Supplier Interviews}

This section presents the views of the suppliers for each of the three supply categories.

\subsection{Supplier of external leather - Conceria del Chienti}

Conceria del Chienti, the largest tannery near the Macerata-Fermo district, confirms the main characteristics highlighted by the footwear companies: a high-involvement 
relationship with much uncertainty and fluctuations, as a result of the ever changing fashion trends and the strong interaction that takes place during the collection launch. It highlights mainly the pressure to improve its logistical performance because (with the exception of a few leather types and colours) footwear companies order the precise amount, and whenever they modify their plan they are dependent on the tannery to obtain more/different leather. The CEO of the company highlights: "Once, the footwear companies considered leather as a good investment and, when they had cash, they were inclined to stock relevant leather batches. Nowadays the leather stock is close to zero, given the sudden changes in the colors and tones". At the same time, the supply relationship is very much dependent on a highly variable volume of orders. "They allocate us on certain models and, after, it is like being at a wheel of fortune".

\subsection{Supplier of soles - Finproject}

Finproject, one of the leading soles supplier in the Macerata-Fermo district and the worldwide leader in light soles, confirms the main characteristics highlighted by the footwear companies. The Commercial Director of Finproject confirms there is strong collaboration with the footwear companies during both the design and the production stage. Often Finproject starts producing batches before receiving orders, in the case of some standard articles, as well as for a few customized soles for high importance customers. Such a collaboration helps Finproject to distribute the production for a given fashion season over a longer period, while reducing peaks and limiting the idle times. The resulting cost advantage is shared with the customers. Finproject shares with the footwear companies the investment related to the molds, which represent a strong incentive for buyers to use, at least part of, the existing sole molds the following year - 
thus reducing investment in new molds, and naturally supporting the development of long-term partnerships.

\subsection{Supplier of internal leather - Conceria Tirrena}

Conceria Tirrena, one of the largest European suppliers of internal leather, confirms the main characteristics highlighted by the footwear companies. Conceria Tirrena has very large warehouses and can provide most customers' requests directly from stock, avoiding bottlenecks at the very beginning of the fashion season, as well as in the replenishment stage. Such an approach avoids the need for information sharing, allowing Conceria Tirrena to comply with customers' requirements at very short notice. There is almost no shared investment with customers: even though Conceria Tirrena is willing to share its IT applications for the coding and location identification of leather batches. Although this could reduce material handling costs at the customer side, only a few footwear companies are currently taking advantage of such an opportunity. Conceria Tirrena tries to develop long-term commercial relationships by offering footwear companies long payment terms. The internal leather is generally the first material to be sourced when shoe production is launched and long payment terms allow the footwear company to better manage their cash flow. The CFO of the company reports that "The footwear companies, before negotiating financial support from the banks, come to us to see our payment terms".

These suppliers' views are reported in Table 6 .

TABLE 6 AROUND HERE 


\section{Cross-Case Analysis}

The supply relationships developed by the three case companies for each of the three analyzed supply categories are summarized in Table 7, illustrating a high level of corroboration in the findings from the cases and supplier interviews. There is widespread presence of high-involvement supply partnerships for external leather and sole suppliers. Given the time pressure in developing and producing new collections, the role of suppliers is key to the novelty of the product design and the responsiveness required in the marketplace, for which knowledge sharing is critical. Investment in relationship-specific assets is also an approach used by many footwear companies, especially with respect to the non-leather soles producers. Further, for these two categories most of the supply relationships are managed in an informal way and the use of formal contracts is mainly sought for administrative purposes. By contrast, supplier relationships for internal leather are of low involvement, as indicated by virtually no knowledge sharing and predominantly formal contract-based governance mechanisms.

TABLE 7 AROUND HERE

\subsection{Supply relationships in the external leather category}

All three case companies consider suppliers of external leather as valuable, but this does not appear to influence the expected length of supply relationships. Instead, stylists 
decide on the leather that matches their ideas for the collection and this drives supplier selection. Fit with fashion trends is much more important than past performance. However, when possible, footwear companies will give priority to suppliers they already know and will turn away from suppliers that, in spite of their innovation, have underperformed on quality or delivery. Moreover, even without a long-term horizon, these three companies try and develop high-involvement collaboration, mainly in terms of knowledge sharing and informal governance mechanisms.

The evidence confirms that partnerships with external leather suppliers are characterized by a few long-term relationships and a series of short-term, more volatile relationships. To choose the external leather that best fits with fashion trends, footwear companies have built up a wide supplier base among which - season by season - they can choose the leather considered to be most in line with the market requirements.

\subsection{Supply relationships in the soles category}

All three case companies consider suppliers of soles as valuable and they are establishing long-term relationships with the suppliers, with the exception of suppliers of leather soles, which are sometimes considered a commodity. In most cases the suppliers are considered the "product expert" and have the technical skills to match stylists' ideas for the next fashion season. Therefore, these case companies will give priority to suppliers they already know, and that have performed well during the collection development stage, as well as having a good track record on quality and delivery. Contractual agreements are limited to a single season but there are mechanisms (including the possibility to re-use some sole molds in the following season) that make the relationship stable across seasons. 
Based on this evidence, it appears that relationships with soles producers can be classified predominantly as high-involvement and long-term. The need for a wide variety of soles can, in most cases, be obtained by leveraging on existing suppliers and the possibility of carrying over a given sole into the following season is carefully considered to avoid additional investments. Such supply partnerships are used to develop a cooperation that might contribute to increased reliability and responsiveness, given that many processes are informal and can be fine-tuned only through mutual experience. There are, however, a few high-involvement and short-term relationships, used to widen the collection portfolio to new materials and new processes.

\subsection{Supply relationships in the internal leather category}

All three case companies consider the relationship with the suppliers of internal leather as not critical, given that, with very few exceptions, the internal leather has a very limited impact on the "look and feel" of the footwear collection and can be considered a commodity. The choice of the supplier is mainly driven by availability and cost issues with no need for establishing high-involvement relationships, so they tend to be shortterm and transaction based.

\section{Proposition Formulation}

The evidence indicates that in the fashion footwear industry, given the fast pace of the collection development and launch, together with a high degree of outsourcing towards specialized suppliers, agile footwear companies look for high-involvement relationships (i.e. supply partnerships) in order to be able to successfully manage an almost complete renewal of their product portfolio every season. In such a context ASPs are 
predominantly used for the supply category that is most influenced by the fashion trends: the external leather. It is only in this category that footwear companies might not renew partnerships with suppliers that have a good performance track record, because their capabilities do not fit with the new fashion collection requirements.

The evidence from the three main cases - confirmed by the interviews with leading district suppliers - leads to the following propositions, which address the first research question on the conditions for ASPs:

P1. Agile fashion footwear companies seek supply partnerships to achieve quality and responsiveness.

P2. Agile fashion footwear companies, while preferring long-term partnerships, accept short-term partnerships in supply categories which are highly influenced by fashion trends.

TABLE 8 AROUND HERE

Propositions that address the second research question, on the characteristics of ASPs, are developed through an analysis of the evidence presented in Table 8.

The ASPs identified in this research always complement long-term relationships in an agile supply chain. The high level of turbulence driven by a high renewal rate in the collection portfolio (and by unpredictable changes in demand) where existing capabilities were no longer appropriate for the fashion season, prompted companies to rely on a portfolio of long-term and short-term partnerships. 
P3. ASPs exist alongside long-term partnerships, forming a portfolio of complementary relationships.

The complementarity of long- and short-term relationships as a response to turbulence has previously been alluded to in the literature. Tran (2010) indicates that the development of fashion collections might require both long- and short-term relationships. Doyle et al. (2006) argue that the process of terminating ongoing relationships and selecting new suppliers is costly and time-consuming, therefore no company was targeting only ASPs. This is also consistent with Phillips et al.'s (2006) findings in the context of disruptive innovations, where they claim that "the firm not only needs to build new linkages but also to complement these with an established pattern of long-term relationships" (p. 451).

The ASPs identified in this research are linked to the tightly time-constrained development and launch of a specific range of models for a new fashion collection, a scenario with project-like features. During the period of the project, the partnering companies need to develop a deep relationship, but they might not collaborate again, at least for some years, in joint projects, which leads to proposition 4:

P4. ASPs have project-like features in that they are established for the tightly timeconstrained development and launch of specific product ranges.

These features are reported in the literature, in industries such as construction or events management, where a major task has to be achieved in a short time by a group of companies that are then disbanded after the objective is reached (Gadde and Dubois, 2010).

Given the short reaction time required by an agile strategy, these ASPs are mainly developed starting from a group of pre-qualified suppliers. The footwear companies 
have developed a network of suppliers with known capabilities and operating performance, from within which they select each season, leading to proposition 5:

P5. Suppliers in ASPs are often selected from a network of pre-qualified suppliers which have been previously tested and demonstrated performance.

Pre-qualification can be limited to a previous involvement just in the collection development phase, or it might leverage on a full involvement in the collection production phase. Pre-qualification with the purpose of quick response has already been found in the fashion industry (Masson et al., 2007) as well as in different contexts such as the high-tech clusters (Katzy and Crowston, 2008).

Normally a company would pre-qualify suppliers with whom it is collaborating intensively on a recurrent, rather than continuous, basis (Christopher et al., 2004), where each period of collaboration can be classed as short-term. Thus "dormant" supply relationships can be reactivated for a season, allowing an already established relationship to be quickly revived to face the time pressured challenges of a fashion collection development and production. This leads to proposition 6:

P6. ASPs tend to be intermittent and recurrent, rather than continuous or one-off shortterm, in response to fashion trends.

Intermittent and recurrent relationships have been found at the strategic level by Ozcan and Eisenhardt (2009) when, in analyzing the development of alliance portfolios in the wireless gaming industry, they found the use of "sequential attention" in order to maintain open the collaboration towards a wide network. In an agile supply chain such relationships play an important role as they can leverage on the fine-tuning already established and the experience already acquired (the reciprocal knowledge), being activated for the short-term periods when they are required. 


\section{Conclusions, Limitations and further Research}

In this research we set out to investigate Agile Supply Partnerships (ASPs) in the fashion footwear industry. ASPs appear to be relevant in supply categories which have a high impact on the appearance or functionality of the product, and therefore the competences and specialization of existing suppliers might not be sufficiently broad to comply with changing fashion trends. Conversely, in supply categories where there is a lower impact by fashion trends, companies appear to favour traditional long-term partnerships.

Four main characteristics of ASPs were identified. Firstly, as ASPs give advantages in terms of novelty and innovation, but lose some advantages of long-term partnerships, they are never the only kind of supply partnership for a given supply category. ASPs are developed by footwear companies as part of a portfolio of relationships to balance the rigidities of long-term strategic partnerships. Secondly, ASPs have project-like features where they are focused on the development and launch of specific products for a particular season under significant time pressure. Thirdly, ASPs are mainly developed starting from a network of pre-qualified suppliers with known capabilities and performance. Finally, ASPs are recurring and intermittent rather than continuous or isolated one-off short-term partnerships.

This research contributes to the literature on agility by: empirically analyzing the apparent paradox related to the specific characteristics of supply relationships required to foster an agile strategy; clarifying the conditions under which fashion companies develop ASPs; and highlighting the necessary characteristics that are required to operate under high levels of turbulence. 
The managerial implications of this research are for decision makers in the fashion industry and potentially other sectors affected by high turbulence. The practices for defining when to establish an ASP refer to the strategic decision of having agility as a competitive priority, as well as the definition of the supply category. As reported in the cases, the only companies that are establishing ASPs are those that strategically target a "high turbulence" agility. While companies in different industries will have different agility drivers, it can be assumed that those pursuing this type of agile strategy will have an interest in evaluating ASPs, and possibly implementing them in supply categories that have an impact on the customer perceived product variety or differentiation. This research provides useful guidelines for practitioners regarding, the suitability of ASPs, and the specific characteristics they need to have to support an agile strategy in and increasingly turbulent environment.

A qualitative exploratory approach was followed, based on case studies carried out in the context of an Italian footwear district. The chosen research design has two major limitations. Firstly, the data were collected mainly through interviews and company reports with limited access to longitudinal data. Longitudinal data would be valuable to investigate more precisely the durations of partnerships and how they evolve over time, for example in relation to the industry clockspeed. Moreover an increased level of study participation from the suppliers, together with a one-to-one matching for specific supply relationships, could strengthen the understanding of both buyer and supplier perspectives. Secondly, the context of the research impacts on the external validity of the results, as case studies rely on analytical rather than statistical generalization.

Given that increased turbulence is affecting a growing number of industries, further research on the conditions for, and characteristics of, ASPs appears relevant to 
overcome - both in theory and practice - the apparent paradox of high-involvement yet short-term supply relationships.

\section{References}

Assocalzaturifici (2014). L'industria calzaturiera in Italia. Lineamenti principali 2013 [Footwear industry in Italy. Overview 2013], Assocalzaturifici, Milano.

Baramichai, M., Zimmers, E.W. Jr and Marangos, C.A. (2007). "Agile supply chain transformation matrix: An integrated tool for creating an agile enterprise". Supply Chain Management, vol. 12, no. 5, pp. 334-348.

Cerruti, C. and Tavoletti, E. (2012). L'innovazione commerciale e logistica nel distretto fermano-maceratese. In, Economia e Management delle Imprese Calzaturiere, Confindustria-ANCI (eds.), Milano: Franco Angeli Editore, pp.123-135

Christopher, M. (2000). “The Agile Supply Chain”. Industrial Marketing Management, vol. 29 , no. 1, pp. 37-44.

Christopher, M. and Holweg, M. (2011). "Supply Chain 2.0": managing supply chains in the era of turbulence", International Journal of Physical Distribution \& Logistics Management, vol. 41, no. 1, pp. 63-82.

Christopher, M., Lowson, R. and Peck, H. (2004). "Creating agile supply chains in the fashion industry". International Journal of Retail \& Distribution Management, vol. 32, pp. 367-376.

Doyle, S.A., Moore, C.M. and Morgan, L. (2006). "Supplier management in fast moving fashion retailing". Journal of Fashion Marketing \& Management, vol. 10 , no. 3, pp. 272-281.

Drake, P.R., Lee, D.M. and Hussain, M. (2013). "The lean and agile purchasing portfolio model”. Supply Chain Management: An International Journal. Vol. 18 no. 1 , pp. 3-20.

Dyer, J.H. and Nobeoka, K. (2000). "Creating and managing a high-performance knowledge-sharing network: The Toyota case". Strategic Management Journal, vol. 21 , no. 3 , pp. $345-367$.

Dyer, J.H. and Singh, H. (1998). "The relational view: cooperative strategy and sources of interorganizational competitive advantage". Academy of Management Review, vol. 23, no. 4, pp. 660-679.

Eisenhardt, K.M. (1989). "Building Theories from Case Study Research". Academy of Management Review, vol. 14. No. 4, pp. 532-550. 
Fine, C. (1998). Clocks Speed: Winning Industry Control in the Age of Temporary Advantage, Perseus Books, Reading, Massachusetts, USA

Ford, D. Gadde, L, Håkansson, H., \& Snehota, I. (2011). Managing Business Relationships, Chichester, West Sussex, Wiley.

Gadde, L.E. and Dubois, A. (2010). "Partnering in the construction industry - Problems and opportunities". Journal of Purchasing \& Supply Management, vol. 16, no. 4, pp. 254-263.

Gligor, D.M. (2014). The role of demand management in achieving supply chain agility, Supply Chain Management: An International Journal, vol. 19, no. 5/6, pp. 577591.

Gligor, D.M. and Holcomb, M.C. (2012). "Understanding the role of logistics capabilities in achieving supply chain agility: a systematic literature review". Supply Chain Management: An International Journal, vol. 17, no. 4, pp. 438453.

Goldman, S.L., Nagel, R.N. and Preiss, K. (1995). Agile Competitors and Virtual Organizations: Strategies for Enriching the Customer. New York, Van Nostrand Reinhold, USA.

Gunasekaran, A. (1998). "Agile manufacturing: Enablers and an implementation framework". International Journal of Production Research, vol. 36, no. 5, pp. 1223-1247.

Katzy, B.R. and Crowston, K. (2008). "Competency rallying for technical innovation The case of the Virtuelle Fabrik". Technovation, vol. 28, no. 10, pp. 679-692.

Masson, R., Iosif, L., MacKerron, G. and Fernie, J. (2007). "Managing complexity in agile global fashion industry supply chains". International Journal of Logistics Management, vol. 18, no. 2, pp. 238-254.

Mena, C., Christopher, M., Johnson, M. and Jia, F. (2007). Innovation in Logistics Services, Report has been produced by Cranfield University for NESTA. Available from: http://scholar.google.co.uk/scholar?oi=bibs\&cluster= $724107935598046261 \&$ btnI $=1 \&$ hl=en (last visited 23/03/2015)

Mesquita, L.F. and Brush, T.H. (2008). "Comparing the resource-based and the relational views: Knowledge transfer and spillover in vertical alliances". Strategic Management Journal, vol. 29, no. 9, pp. 913-941.

Miles, M.B. and Huberman, A.M. (1994). Qualitative Data Analysis: An Expanded Sourcebook, Thousand Oaks, CA. Sage Publications.

Narayanan, S. Narasimhan, R. and Schoenherr, T. (2015). "Assessing the contingent effects of collaboration on agility performance in buyer-supplier relationships", Journal of Operations Management, vol. 33-34, pp. 140-154.

Ozcan, P. and Eisenhardt K.M. (2009). "Origin of Alliance Portfolios: Entrepreneurs, Network Strategies, and Firm Performance". Academy of Management Journal, vol. 52, no. 2, pp. 246-279. 
Phillips, W., Lamming, R., Bessant, J. and Noke, H. (2006). "Discontinuous innovation and supply relationships: strategic alliances". $R \& D$ Management, vol. 36 , no. 4, pp. 451-461.

Ploetner, O. and Ehret, M. (2006). "From relationships to partnerships: New forms of cooperation between buyer and seller". Industrial Marketing Management, vol. 35 , pp. 4-9.

Sproles, G.B. (1981). "Analyzing fashion life cycles: principles and perspectives". Journal of Marketing, vol. 45, no. 4, pp.116-124.

Storey, J., Emberson, C. and Reade, D. (2005). "The barriers to customer responsive supply chain management". International Journal of Operations \& Production Management, vol. 25, no. 3, pp. 242-260.

Swafford, P.M., Ghosh, S. and Murthy, N.N. (2006). "A framework for assessing value chain agility". International Journal of Operations \& Production Management, vol. 26, no. 2, pp. 118-140.

Tavani S.N., Sharifi H. and Ismail H.S. (2014). "A study of contingency relationships between supplier involvement, absorptive capacity and agile product innovation". International Journal of Operations \& Production Management, vol. 34, no. 1, pp. 65-92.

Tran, Y. (2010). “Generating Stylistic Innovation: A Process Perspective”. Industry \& Innovation, vol. 17, no. 2, pp. 131-161.

van Hoek, R.I., Harrison, A. and Christopher, M. (2001). "Measuring agile capabilities in the supply chain". International Journal of Operations \& Production Management, vol. 21, no. 1, pp. 126-147.

Vázquez-Bustelo, D., Avella, L. and Fernandez, E. (2007). “Agility drivers, enablers and outcomes". International Journal of Operations \& Production Management, vol. 27 , no. 12 , pp. 1303-1332.

Williamson, O.E. (1985). The Economic Institutions of Capitalism, New York: The Free Press.

Yin, R.K. (2014). Case Study Research: Design and Methods. Sage Publications, Thousand Oaks, CA. (Fifth Edition).

Yusuf, Y. Y., Sarhadi, M., \& Gunasekaran, A. (1999). “Agile manufacturing: The drivers, concepts and attributes". International Journal of production economics, vol. 62 , no. 1 , pp. 33-43.

Yusuf, Y.Y., Gunasekaran, A., Adeleye, E.O. and Sivayoganathan, K. (2004). "Agile supply chain capabilities: Determinants of competitive objectives". European Journal of Operational Research, vol. 159, no. 2, pp. 379-392.

Zaheer, A. and Venkatraman, N. (1995). "Relational governance as an interorganizational strategy; An empirical test of the role of trust in economic exchange". Strategic Management Journal, vol. 16, pp. 373-392. 
Zhang, D.Z. (2011). "Agile manufacturing strategies - Case studies of an agility taxonomy”. International Journal of Production Economics, vol. 131, no. 1, pp. 303-312.

Zhang, D.Z. and Sharifi, H. (2000). "A methodology for achieving agility in manufacturing organizations". International Journal of Operations \& Production Management, vol. 20, no. 4, pp. 496-512. 


\section{Appendix A - Interview protocols}

\section{First round interviews}

Questions on "high-involvement" supply relationships

- Knowledge and high-value information sharing with suppliers

- Relationship-specific investments towards suppliers

- Trust-based agreement with suppliers

Questions on time frame reference for "high-involvement" relationships

- "High-involvement \& long-term" supply relationships

- "High-involvement \& short-term" supply relationships

\section{Second round interviews}

Comments on your company supply strategy

- Your supply strategies in each of the selected supply categories

- Main elements driving your company to differentiate the supply relationship by product category

Reasons for developing supply partnerships

- Factors in the competitive environment driving you to establish supply partnerships

- Relevance of these factors in each of the selected supply categories

- Performance targets driving you to establish supply partnerships

- Relevance of these targets in each of the selected supply categories 
Appendix B - Interviews reference data

\begin{tabular}{|c|c|c|c|c|}
\hline Phase & Company & Role(s) & $\begin{array}{l}\text { Number of } \\
\text { interviews }\end{array}$ & $\begin{array}{l}\text { Total duration } \\
\text { (in minutes) }\end{array}$ \\
\hline \multirow[t]{2}{*}{ Preliminary } & $\begin{array}{l}\text { Confindustria Macerata } \\
\text { (Industrial Association) }\end{array}$ & $\begin{array}{l}\text { Delegate to the footwear industry } \\
\text { Board members }\end{array}$ & 4 & 125 \\
\hline & $\begin{array}{l}\text { Confindustria } \quad \text { Fermo } \\
\text { (Industrial Association) }\end{array}$ & $\begin{array}{l}\text { Delegate to the footwear industry } \\
\text { Board members }\end{array}$ & 2 & 75 \\
\hline \multirow{3}{*}{$\begin{array}{l}\text { Case } \\
\text { companies }\end{array}$} & Manas & General Manager & 4 & 192 \\
\hline & Fabi & Owner-CEO & 4 & 174 \\
\hline & Cesare Paciotti & General Manager & 4 & 155 \\
\hline \multirow[t]{3}{*}{ Suppliers } & $\begin{array}{l}\text { Conceria del Chienti } \\
\text { (external leather supplier) }\end{array}$ & $\mathrm{CEO}$ & 1 & 59 \\
\hline & $\begin{array}{l}\text { Finproject } \\
\text { (soles supplier) }\end{array}$ & Commercial Director & 1 & 62 \\
\hline & $\begin{array}{l}\text { Conceria Tirrena } \\
\text { (internal leather supplier) }\end{array}$ & $\mathrm{CFO}$ & 1 & 80 \\
\hline
\end{tabular}




\section{Footwear Company Cases}
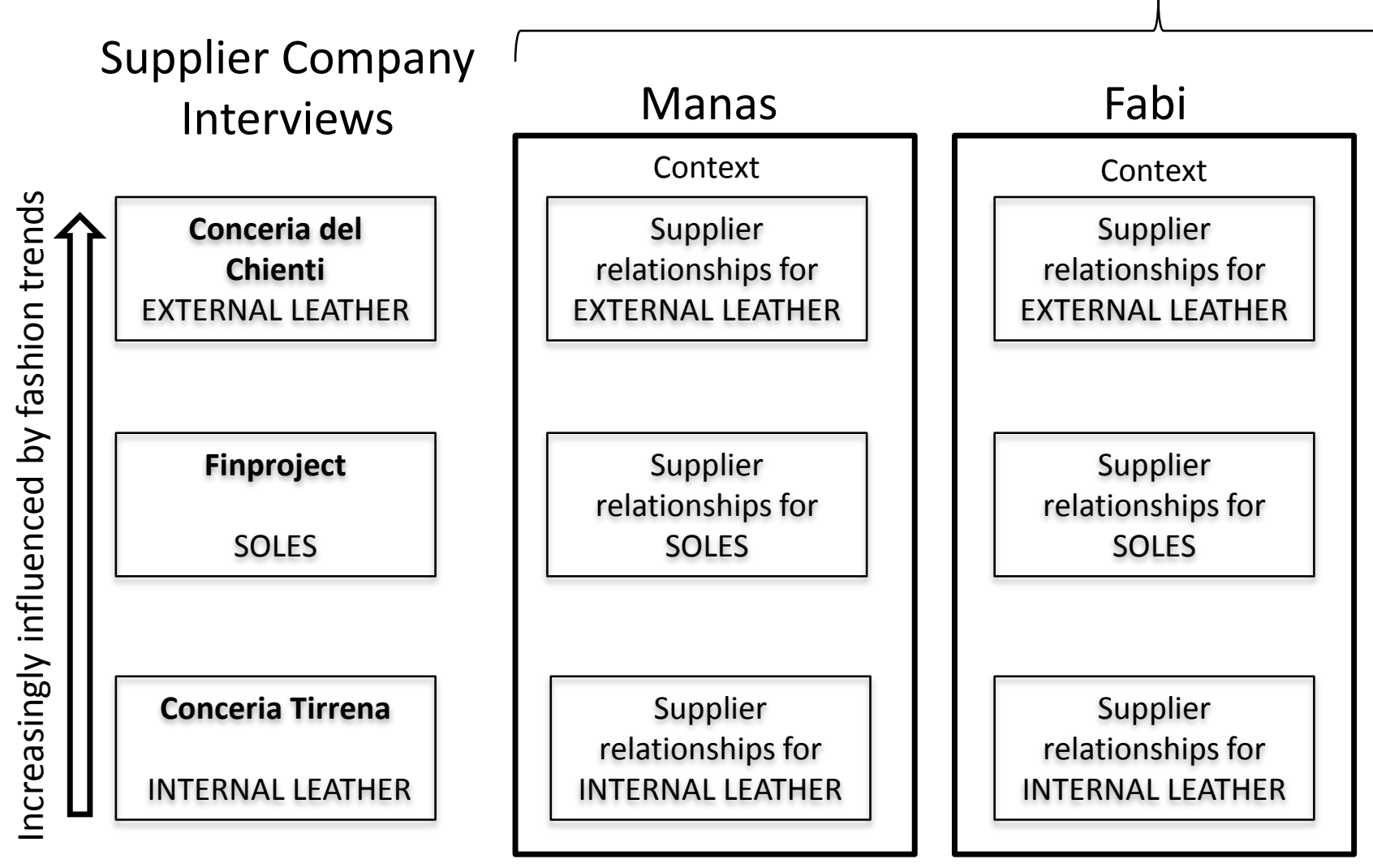

Cesare Paciotti

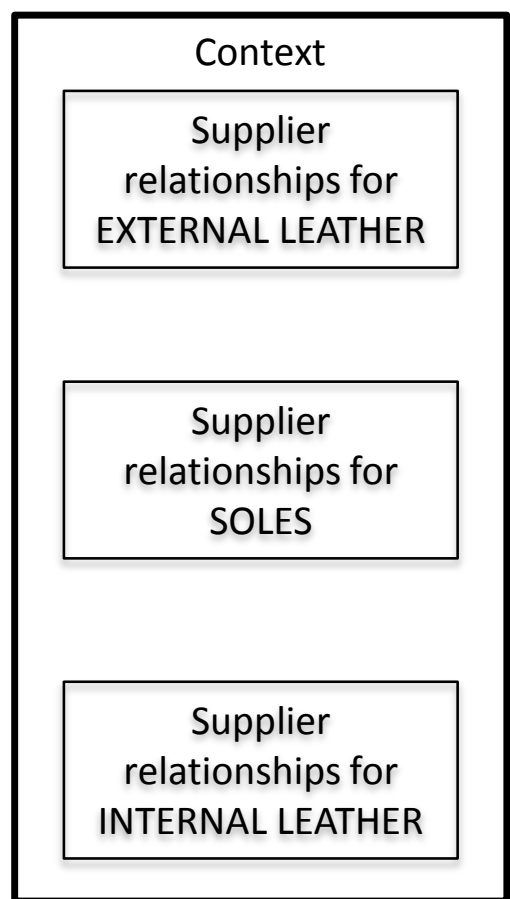

Figure 1: Research design showing the multiple embedded case studies 
Table 1: Quality criteria

\begin{tabular}{|c|c|}
\hline $\begin{array}{l}\text { Construct } \\
\text { validity }\end{array}$ & $\begin{array}{l}\text { - Multiple sources of evidence were used (Eisenhardt, 1989; Yin, 2014). } \\
\text { - Key informants were in top management positions - owner, CEO or General } \\
\text { Manager - having full visibility of and responsibility for the strategy and processes. } \\
\text { - Construct operationalization was supported by the literature review. }\end{array}$ \\
\hline $\begin{array}{l}\text { Internal } \\
\text { validity }\end{array}$ & $\begin{array}{l}\text { - } \quad \text { Assured through pattern matching (Yin, 2014). } \\
\text { - } \quad \text { All case studies selected from a single context. }\end{array}$ \\
\hline $\begin{array}{l}\text { External } \\
\text { validity }\end{array}$ & $\begin{array}{l}\text { - Achieved through analytic generalization and replication logic (Yin, 2014). } \\
\text { - Three longitudinal cases of companies that are highly likely to be involved in agile } \\
\text { supply partnerships. } \\
\text { - } \quad \text { Limited by the fact that all the case studies are taken from a single context. }\end{array}$ \\
\hline Reliability & $\begin{array}{l}\text { - Reliability is achieved here through transparency of the process (Yin, 2014). } \\
\text { - The case study protocol defines the way the data were collected. } \\
\text { - In the data collection phase a case study database has been developed. } \\
\text { - Draft case studies prepared and validated by each case company. }\end{array}$ \\
\hline
\end{tabular}


Table 2: Overview of case companies (2013)

\begin{tabular}{|l|c|c|c|}
\hline & Manas & Fabi & Cesare Paciotti \\
\hline Market segment positioning & Medium-High & High & 42.0 \\
\hline Turnover 2013 (in mil. euro) & 22.4 & 44.3 & $100 \%$ \\
\hline Collection renewal rate (\% of new articles in collection) & $97 \%$ & $90 \%$ & $100 \%$ \\
\hline Samples produced in the District (in \%) & $100 \%$ & $100 \%$ & $100 \%$ \\
\hline Cutting \& sewing carried out in the District (in \%) & $100 \%$ & $80 \%$ & $100 \%$ \\
\hline Final assembling carried out in the District (in \%) & $100 \%$ & $100 \%$ & $35 \%$ \\
\hline Leather purchased before the fashion fairs (in \%) & $30 \%$ & $30 \%$ & $30 \%$ \\
\hline Production orders issued before the fashion fairs (in \%) & $0 \%$ & $20 \%$ & \multirow{2}{*}{. } \\
\hline
\end{tabular}


Table 3: Manas's approach to supply relationships.

\begin{tabular}{|c|c|c|c|}
\hline & $\begin{array}{c}\text { EXTERNAL LEATHER } \\
\text { SUPPLIERS } \\
\text { (highly influenced by fashion trends) }\end{array}$ & $\begin{array}{c}\text { SOLES SUPPLIERS } \\
\text { (influenced by fashion trends) }\end{array}$ & $\begin{array}{c}\text { INTERNAL LEATHER } \\
\text { SUPPLIERS } \\
\text { (not influenced by fashion trends) } \\
\end{array}$ \\
\hline $\begin{array}{l}\begin{array}{l}\text { Level of } \\
\text { involvement }\end{array} \\
\text { in supplier } \\
\text { relationships } \\
\text { - Inter-firm } \\
\text { knowledge } \\
\text { sharing } \\
\text { routines }\end{array}$ & $\begin{array}{l}\text { Information sharing with suppliers is a } \\
\text { continuous process, both during the } \\
\text { collection preparation and the } \\
\text { production/delivery phase. In spite of } \\
\text { such information exchange, the external } \\
\text { leather suppliers still represent a major } \\
\text { bottleneck which prevents Manas from } \\
\text { achieving good performance and they } \\
\text { are working hard to further develop } \\
\text { information exchange. } \\
\text { Hence inter-firm knowledge sharing } \\
\text { is HIGH. }\end{array}$ & $\begin{array}{l}\text { Information sharing with soles } \\
\text { suppliers is regular during } \\
\text { collection preparation and the } \\
\text { production phases. Soles } \\
\text { suppliers are all located nearby } \\
\text { and this facilitates information } \\
\text { sharing. The information } \\
\text { exchange is daily and total, given } \\
\text { that suppliers know the } \\
\text { importance of their supply. } \\
\text { Hence inter-firm knowledge } \\
\text { sharing is HIGH. }\end{array}$ & $\begin{array}{l}\text { Knowledge sharing is neither } \\
\text { important during the development } \\
\text { stage, as the internal leather is a } \\
\text { fairly standard material, nor during } \\
\text { the production phase, as the internal } \\
\text { leather is used across several } \\
\text { models thereby reducing demand } \\
\text { fluctuations. } \\
\text { Hence inter-firm knowledge } \\
\text { sharing is in general } \\
\text { LOW/NONE. }\end{array}$ \\
\hline $\begin{array}{l}\text { - Investment } \\
\text { in relation- } \\
\text { specific } \\
\text { assets }\end{array}$ & $\begin{array}{l}\text { Generally no relation-specific } \\
\text { investments. The collaboration with the } \\
\text { tanneries in the development phase is } \\
\text { mainly based on the seasonal leather } \\
\text { collection proposed by the tanneries, } \\
\text { rather than the joint development. } \\
\text { Hence investment in relation-specific } \\
\text { assets is NONE. }\end{array}$ & $\begin{array}{l}\text { Manas shares investments with } \\
\text { soles suppliers when they develop } \\
\text { customized molds exclusive to } \\
\text { them. }\end{array}$ & $\begin{array}{l}\text { Hence investment in relation- } \\
\text { specific assets is NONE. }\end{array}$ \\
\hline $\begin{array}{l}\text { - Self- } \\
\text { enforcement } \\
\text { governance } \\
\text { mechanisms }\end{array}$ & $\begin{array}{l}\text { Governance mechanisms are generally } \\
\text { informal. "There is a long list of } \\
\text { contingencies that are governed by a } \\
\text { handshake more than by a written } \\
\text { agreement. There is a relationship that } \\
\text { is based on trust that goes beyond the } \\
\text { contract". } \\
\text { Hence the presence of self- } \\
\text { enforcement governance mechanisms } \\
\text { is HIGH. }\end{array}$ & $\begin{array}{l}\text { Governance mechanisms are } \\
\text { generally informal. } \\
\text { A key consideration is the ability } \\
\text { of the supplier to support frequent } \\
\text { re-planning of production. } \\
\text { Hence the presence of self- } \\
\text { enforcement governance } \\
\text { mechanisms is HIGH. }\end{array}$ & $\begin{array}{l}\text { Governance mechanisms are quite } \\
\text { formal, as they need to deal with } \\
\text { fewer contingencies. }\end{array}$ \\
\hline $\begin{array}{l}\text { Relationship } \\
\text { duration } \\
\text { (specific to } \\
\text { materials) }\end{array}$ & $\begin{array}{l}\text { Even if a reliable and stable supply base } \\
\text { is important, Manas regularly looks for } \\
\text { new suppliers to widen and refresh their } \\
\text { collection as well as it leaves aside } \\
\text { "high-performing" suppliers due to } \\
\text { fashion trends. }\end{array}$ & $\begin{array}{l}\text { Supply relationships tend to be } \\
\text { stable. Partnerships are } \\
\text { considered important. Manas } \\
\text { relies on few suppliers (3-5), with } \\
\text { limited turnover but with some } \\
\text { volume fluctuation. } \\
\text { Even though most shoes are } \\
\text { redesigned every season, soles are } \\
\text { often maintained. } \\
\text { Hence the relationships are } \\
\text { PREDOMINANTLY LONG } \\
\text { TERM. }\end{array}$ & $\begin{array}{l}\text { Partnerships with internal leather } \\
\text { suppliers are not a priority. Every } \\
\text { season only four to five different } \\
\text { suppliers are used. } \\
\text { Costs and material availability } \\
\text { determine the volume allocation. }\end{array}$ \\
\hline $\begin{array}{l}\text { Types of } \\
\text { relationships }\end{array}$ & Mainly HI-ST & Mainly HI-LT & $\begin{array}{l}\text { Mainly LO-ST (even if some of } \\
\text { them can be durable LO) }\end{array}$ \\
\hline
\end{tabular}


Table 4: Fabi's approach to supply relationships.

\begin{tabular}{|c|c|c|c|}
\hline & $\begin{array}{c}\text { EXTERNAL LEATHER } \\
\text { SUPPLIERS } \\
\text { (highly influenced by fashion trends) }\end{array}$ & $\begin{array}{c}\text { SOLES SUPPLIERS } \\
\text { (influenced by fashion trends) }\end{array}$ & $\begin{array}{c}\text { INTERNAL LEATHER } \\
\text { SUPPLIERS } \\
\text { (not influenced by fashion trends) }\end{array}$ \\
\hline $\begin{array}{l}\text { Level of } \\
\text { involvement } \\
\text { for supplier } \\
\text { relationships } \\
\text { - Inter-firm } \\
\text { knowledge } \\
\text { sharing } \\
\text { routines }\end{array}$ & $\begin{array}{l}\text { Knowledge sharing is critical during } \\
\text { the development stage where the stylist } \\
\text { fine-tunes a given set of models with } \\
\text { the creative inputs of the external } \\
\text { leather suppliers. } \\
\text { Knowledge sharing is also important } \\
\text { during production to support frequent } \\
\text { rescheduling. } \\
\text { Hence inter-firm knowledge sharing } \\
\text { is HIGH. }\end{array}$ & $\begin{array}{l}\text { Knowledge sharing is } \\
\text { important during the } \\
\text { development stage given that } \\
\text { Fabi relies on its non-leather } \\
\text { soles suppliers to contribute to } \\
\text { the final look of a model. } \\
\text { During the production stage, } \\
\text { knowledge sharing is important } \\
\text { due to changes in production } \\
\text { plans. } \\
\text { Soles are a critical element as } \\
\text { they are size-specific and } \\
\text { model-specific. } \\
\text { Hence inter-firm knowledge } \\
\text { sharing is HIGH. }\end{array}$ & $\begin{array}{l}\text { Knowledge sharing is not important } \\
\text { during the development stage as the } \\
\text { new models often use standard } \\
\text { internal leather supplies with no need } \\
\text { to interact with the suppliers. } \\
\text { Knowledge sharing is not important } \\
\text { during the production phase as, } \\
\text { despite frequent rescheduling, internal } \\
\text { leather can be used in many models } \\
\text { and it is often purchased in bulk at the } \\
\text { beginning of the season. }\end{array}$ \\
\hline $\begin{array}{l}\text { - Investment } \\
\text { in relation- } \\
\text { specific assets }\end{array}$ & $\begin{array}{l}\text { Generally no relation-specific } \\
\text { investments. The development of a new } \\
\text { colour or finishing or the treatment of a } \\
\text { new material is left completely to the } \\
\text { tanneries. } \\
\text { Hence investment in relation-specific } \\
\text { assets is NONE. }\end{array}$ & $\begin{array}{l}\text { Developing a customized sole } \\
\text { requires a significant, dedicated } \\
\text { investment in the molds, which } \\
\text { is disproportionately high } \\
\text { compared to the limited } \\
\text { volumes per item Fabi is } \\
\text { offering on the market. Only } \\
\text { suppliers willing to follow the } \\
\text { company's strategy are selected } \\
\text { but they are supported } \\
\text { regarding mold investments. } \\
\text { Hence investment in relation- } \\
\text { specific assets is HIGH. }\end{array}$ & $\begin{array}{l}\text { Hence investment in relation- } \\
\text { specific assets is NONE. }\end{array}$ \\
\hline $\begin{array}{l}\text { - Self- } \\
\text { enforcement } \\
\text { governance } \\
\text { mechanisms }\end{array}$ & $\begin{array}{l}\text { The governance mechanisms are } \\
\text { strongly based on trust where fairness } \\
\text { is paramount. "Formal detailed } \\
\text { contracts would not allow the flexibility } \\
\text { required to make subjective judgments } \\
\text { on, for instance, the quality of the } \\
\text { leather". } \\
\text { The selection of external leather is } \\
\text { made by the owner on the basis of } \\
\text { strong personal relationships. } \\
\text { Hence the presence of self- } \\
\text { enforcement governance mechanisms } \\
\text { is HIGH. }\end{array}$ & $\begin{array}{l}\text { The governance mechanisms } \\
\text { are mainly based on a formal } \\
\text { contract together with trust- } \\
\text { based mechanisms for the } \\
\text { delivery plans. } \\
\text { Formal detailed contracts } \\
\text { would not allow the flexibility } \\
\text { required during the production } \\
\text { phase. }\end{array}$ & $\begin{array}{l}\text { Governance is based mainly on } \\
\text { contracts. The demand for internal } \\
\text { leather is stable and tends not to } \\
\text { change seasonally. Thereby inventory } \\
\text { represents a lower risk and the } \\
\text { contracts can be specific. } \\
\text { The pricing and financial conditions } \\
\text { are well specified. }\end{array}$ \\
\hline $\begin{array}{l}\text { Relationship } \\
\text { duration }\end{array}$ & $\begin{array}{l}\text { Every supplier (tannery) is specialized } \\
\text { and gives the leather a special look, } \\
\text { therefore suppliers tend to change } \\
\text { every season. Almost all of the selected } \\
\text { suppliers have supplied Fabi before: } \\
\text { "External leather cyclically changes } \\
\text { and when the fashion trend again } \\
\text { requires a certain type of leather, the } \\
\text { suppliers we already know are the first } \\
\text { to be contacted". } \\
\text { Hence the relationships are } \\
\text { PREDOMINANTLY SHORT } \\
\text { TERM. }\end{array}$ & $\begin{array}{l}\text { Only a few local suppliers are } \\
\text { able to develop and deliver } \\
\text { soles with the quality and } \\
\text { timing required. Hence, } \\
\text { partnerships tend to be long- } \\
\text { term with the identified small } \\
\text { list of selected suppliers. }\end{array}$ & $\begin{array}{l}\text { The internal leather is less sensitive to } \\
\text { fashion trends and therefore is } \\
\text { purchased in large lots and with } \\
\text { standard characteristics. There is no } \\
\text { need to establish a relationship with } \\
\text { any player, even if a few of them have } \\
\text { been regular suppliers over the years. }\end{array}$ \\
\hline $\begin{array}{l}\text { Types of } \\
\text { relationships }\end{array}$ & Mainly HI-ST. & Mainly HI-LT. & $\begin{array}{l}\text { Mainly LO-ST (some of them can be } \\
\text { durable LO). }\end{array}$ \\
\hline
\end{tabular}




\begin{tabular}{|c|c|c|c|}
\hline & $\begin{array}{l}\text { EXTERNAL LEATHER } \\
\text { SUPPLIERS } \\
\text { (highly influenced by fashion } \\
\text { trends) }\end{array}$ & $\begin{array}{c}\text { SOLES SUPPLIERS } \\
\text { (moderately influenced by } \\
\text { fashion trends) }\end{array}$ & $\begin{array}{c}\text { INTERNAL LEATHER } \\
\text { SUPPLIERS } \\
\text { (not influenced by fashion trends) }\end{array}$ \\
\hline $\begin{array}{l}\text { Level of } \\
\text { involvement } \\
\text { in supplier } \\
\text { relationships } \\
\text { - Inter-firm } \\
\text { knowledge } \\
\text { sharing } \\
\text { routines }\end{array}$ & $\begin{array}{l}\text { Information sharing is key along the } \\
\text { whole fashion cycle. It is very } \\
\text { important in the case of external } \\
\text { leather since the development stage, } \\
\text { when the stylist is working closely } \\
\text { with the leather supplier to reach } \\
\text { the desired look of the shoes, as } \\
\text { well as during the production stage, } \\
\text { when the external leather might } \\
\text { often represent a bottleneck. } \\
\text { Hence inter-firm knowledge } \\
\text { sharing is HIGH. }\end{array}$ & $\begin{array}{l}\text { Information sharing with soles } \\
\text { suppliers is very important because } \\
\text { they play a key role in the definition } \\
\text { of the specifications and in the } \\
\text { product industrialization. "We bring } \\
\text { our suppliers the idea and they } \\
\text { return to us with the component } \\
\text { fine-tuned. I cannot pretend to } \\
\text { understand rubber better than a } \\
\text { rubber sole producer. It is his job!" } \\
\text { Hence inter-firm knowledge } \\
\text { sharing is HIGH. }\end{array}$ & $\begin{array}{l}\text { Knowledge sharing is not important } \\
\text { as the internal leather is a } \\
\text { commodity. }\end{array}$ \\
\hline $\begin{array}{l}\text { - Investment } \\
\text { in relation- } \\
\text { specific } \\
\text { assets }\end{array}$ & $\begin{array}{l}\text { Hence investment in relation- } \\
\text { specific assets is NONE. }\end{array}$ & $\begin{array}{l}\text { Investment sharing with suppliers is } \\
\text { related to the coverage of the } \\
\text { dedicated investments in the molds } \\
\text { that soles suppliers are casting to } \\
\text { provide Paciotti with customized } \\
\text { soles and that cannot be used for } \\
\text { another company/another model. } \\
\text { Hence investment in relation- } \\
\text { specific assets is HIGH. }\end{array}$ & $\begin{array}{l}\text { Hence investment in relation- } \\
\text { specific assets is NONE. }\end{array}$ \\
\hline $\begin{array}{l}\text { - Self- } \\
\text { enforcement } \\
\text { governance } \\
\text { mechanisms }\end{array}$ & $\begin{array}{l}\text { Governance mechanisms are } \\
\text { informal. Supply contracts specify } \\
\text { the order quantities but external } \\
\text { leather is subject to shrinkage and } \\
\text { imperfections. } \\
\text { Paciotti always select trustworthy } \\
\text { external leather suppliers. } \\
\text { Hence the presence of self- } \\
\text { enforcement governance } \\
\text { mechanisms is HIGH. }\end{array}$ & $\begin{array}{l}\text { Governance mechanisms are } \\
\text { informal. Supply contracts specify } \\
\text { the target quantities and price, but } \\
\text { do not detail logistical aspects. } \\
\text { In case of problems, contractual } \\
\text { clauses related to liability are not } \\
\text { normally applied, because the } \\
\text { parties seek alternative solutions. } \\
\text { Hence the presence of self- } \\
\text { enforcement governance } \\
\text { mechanisms is MEDIUM-HIGH. }\end{array}$ & $\begin{array}{l}\text { Given that the internal leather is a } \\
\text { commodity, supply contracts can be } \\
\text { quite precise, with a limited need } \\
\text { for informal clauses. }\end{array}$ \\
\hline $\begin{array}{l}\text { Relationship } \\
\text { duration }\end{array}$ & $\begin{array}{l}\text { Fashion trends require new } \\
\text { materials, finishes and colours; } \\
\text { therefore almost every season there } \\
\text { is a need for renewal (or } \\
\text { reallocation) of supply contracts. } \\
\text { External leather purchases tend to } \\
\text { be based on recurring short-term } \\
\text { relationships } \\
\text { They don't negotiate long-term } \\
\text { agreements given that each tannery } \\
\text { has very specialist capabilities and a } \\
\text { narrow product range. } \\
\text { Hence the relationships are } \\
\text { PREDOMINANTLY SHORT } \\
\text { TERM. }\end{array}$ & $\begin{array}{l}\text { The company has an established } \\
\text { group of reliable suppliers and there } \\
\text { is no major pressure to revise it. }\end{array}$ & $\begin{array}{l}\text { Suppliers are selected each season } \\
\text { based on their capability to deliver } \\
\text { on time, given that the price is } \\
\text { fairly standard. A long-term } \\
\text { relationship might limit the } \\
\text { possibility to take advantage of } \\
\text { market mechanisms. }\end{array}$ \\
\hline $\begin{array}{l}\text { Types of } \\
\text { relationships }\end{array}$ & Mainly HI-ST & Mainly HI-LT & Mainly LO-ST \\
\hline
\end{tabular}


Table 6: Suppliers' approach to supply relationships

\begin{tabular}{|c|c|c|c|}
\hline & $\begin{array}{c}\text { CONCERIA DEL CHIENTI } \\
\text { EXTERNAL LEATHER } \\
\text { SUPPLIER } \\
\text { (highly influenced by fashion } \\
\text { trends) }\end{array}$ & $\begin{array}{c}\text { FINPROJECT } \\
\text { SOLES SUPPLIERS } \\
\text { (influenced by fashion trends) }\end{array}$ & $\begin{array}{c}\text { CONCERIA TIRRENA } \\
\text { INTERNAL LEATHER } \\
\text { SUPPLIERS } \\
\text { (not influenced by fashion trends) }\end{array}$ \\
\hline $\begin{array}{l}\text { Level of } \\
\text { involvement for } \\
\text { supplier } \\
\text { relationships } \\
\text { - Inter-firm } \\
\text { knowledge } \\
\text { sharing routines }\end{array}$ & $\begin{array}{l}\text { Knowledge sharing with the } \\
\text { customers is very important } \\
\text { during the development and } \\
\text { production phases. However it } \\
\text { could be better structured and } \\
\text { exploited. } \\
\text { "The footwear companies just } \\
\text { choose from the leather collection } \\
\text { samples we have prepared, } \\
\text { without giving us much feedback } \\
\text { at the beginning of the season" } \\
\text { (CEO). } \\
\text { Hence inter-firm knowledge } \\
\text { sharing is generally HIGH. }\end{array}$ & $\begin{array}{l}\text { Knowledge sharing with the } \\
\text { customers is intense both in the } \\
\text { development and in the } \\
\text { production stage. } \\
\text { "The collaboration starts from the } \\
\text { design stage, when we receive the } \\
\text { ideas from our customers and we } \\
\text { transform them into a product, } \\
\text { innovating the design according } \\
\text { to their briefings and managing } \\
\text { all the technical complexities" } \\
\text { (Commercial Director). } \\
\text { Hence inter-firm knowledge } \\
\text { sharing is HIGH. }\end{array}$ & $\begin{array}{l}\text { Knowledge sharing is limited as } \\
\text { they are marginally involved in } \\
\text { the design/stylist aspects of the } \\
\text { collection. Involvement in the } \\
\text { production is also limited, given } \\
\text { that the company has very large } \\
\text { warehouses and can provide most } \\
\text { customers' requests directly from } \\
\text { stock. This avoids the need for } \\
\text { information sharing while } \\
\text { allowing the company to deliver } \\
\text { at very short notice. } \\
\text { Hence inter-firm knowledge } \\
\text { sharing is in general } \\
\text { LOW/NONE. }\end{array}$ \\
\hline $\begin{array}{l}\text { - Investment in } \\
\text { relation-specific } \\
\text { assets }\end{array}$ & $\begin{array}{l}\text { No significant investment sharing } \\
\text { with customers. The company } \\
\text { plans and funds on its own for } \\
\text { new models and new processes. } \\
\text { This lack of investment sharing } \\
\text { might be for historical reasons, } \\
\text { given that in the past tanneries } \\
\text { used to be much larger and richer } \\
\text { than footwear companies. } \\
\text { Hence investment in relation- } \\
\text { specific assets is NONE. }\end{array}$ & $\begin{array}{l}\text { Finproject invests on its own in } \\
\text { the development of a seasonal } \\
\text { collection of soles that can } \\
\text { represent a basis for most of the } \\
\text { customizations for customers. } \\
\text { They share investments related to } \\
\text { specific molds. This represents } \\
\text { an incentive for buyers to re-use } \\
\text { molds and reduces the risk of } \\
\text { termination of the relationship. } \\
\text { Hence investment in relation- } \\
\text { specific assets is HIGH. }\end{array}$ & $\begin{array}{l}\text { No shared investment with } \\
\text { customers, as the footwear } \\
\text { companies appear uninterested } \\
\text { even if the buyer-seller } \\
\text { cooperation could optimize } \\
\text { deliveries and reduce overall } \\
\text { material handling costs. }\end{array}$ \\
\hline $\begin{array}{l}\text { - Self- } \\
\text { enforcement } \\
\text { governance } \\
\text { mechanisms }\end{array}$ & $\begin{array}{l}\text { Governance mechanisms are } \\
\text { strongly based on trust and } \\
\text { fairness. "Imperfections are not } \\
\text { considered a problem by buyers } \\
\text { who have experience in leather } \\
\text { cutting. On the other hand, there } \\
\text { can be difficult discussions, if the } \\
\text { buyer wants to select the leather } \\
\text { while maintaining the same price } \\
\text { per footage" (CEO). Trust is } \\
\text { required on both sides. } \\
\text { Hence the presence of self- } \\
\text { enforcement governance } \\
\text { mechanisms is HIGH. }\end{array}$ & $\begin{array}{l}\text { Governance mechanisms are quite } \\
\text { informal, even if the production } \\
\text { targets of a given fashion season } \\
\text { are defined in advance. They } \\
\text { follow the customers in their re- } \\
\text { planning and sometimes } \\
\text { production is anticipated. } \\
\text { Few formal contracts exist and } \\
\text { tend to be generic and focused on } \\
\text { intellectual property rights or } \\
\text { ethical behaviour, without } \\
\text { detailing specific supply issues. } \\
\text { Hence the presence of self- } \\
\text { enforcement governance } \\
\text { mechanisms is MEDIUM }\end{array}$ & $\begin{array}{l}\text { Governance mechanisms are } \\
\text { closely related to formal aspects, } \\
\text { even if the culture promotes } \\
\text { informal agreement. One of their } \\
\text { main benefits for customers is the } \\
\text { long payment terms offered. } \\
\text { Internal leather is generally the } \\
\text { first material to be sourced and } \\
\text { long payment terms allow the } \\
\text { footwear companies to better } \\
\text { manage cash flow. } \\
\text { Hence the presence of self- } \\
\text { enforcement governance } \\
\text { mechanisms is LOW. }\end{array}$ \\
\hline $\begin{array}{l}\text { Relationship } \\
\text { duration }\end{array}$ & $\begin{array}{l}\text { Duration is subject to uncertainty } \\
\text { due to the fashion trends. With a } \\
\text { few customers they have managed } \\
\text { to maintain a continuous } \\
\text { relationship for many years; but } \\
\text { in some cases they receive orders } \\
\text { just for a few seasons. }\end{array}$ & $\begin{array}{l}\text { Contract duration is in most cases } \\
\text { a single season. However, in } \\
\text { some cases the same soles are } \\
\text { planned for multiple seasons, } \\
\text { implying a longer-term } \\
\text { relationship. } \\
\text { They are deliberately targeting } \\
\text { long-term relationships. } \\
\text { Hence the relationships } \\
\text { PREDOMINANTLY LONG } \\
\text { TERM }\end{array}$ & $\begin{array}{l}\text { They are aware of the market type } \\
\text { relationship. Footwear companies } \\
\text { look at them with a short-term } \\
\text { view of the fashion collection, } \\
\text { focusing on price and availability, } \\
\text { without building long term } \\
\text { relationships, even if most } \\
\text { companies have been sourcing } \\
\text { from them for many years. } \\
\text { Hence the relationships are } \\
\text { PREDOMINANTLY SHORT } \\
\text { TERM }\end{array}$ \\
\hline$\frac{\text { Types of }}{\text { relationships }}$ & Mainly HI-ST & Mainly HI-LT & Mainly LO-ST (mainly durable) \\
\hline
\end{tabular}


Table 7: Overview of the companies' approach to supply relationships

\begin{tabular}{|l|l|l|l|}
\hline & $\begin{array}{c}\text { EXTERNAL LEATHER } \\
\text { (highly influenced by fashion } \\
\text { trends) }\end{array}$ & \multicolumn{1}{|c|}{$\begin{array}{c}\text { SOLES } \\
\text { (influenced by fashion trends) }\end{array}$} & \multicolumn{1}{|c|}{$\begin{array}{c}\text { INTERNAL LEATHER } \\
\text { (not influenced by fashion } \\
\text { trends) }\end{array}$} \\
\hline$\underline{\text { Manas }}$ & Mainly HI-ST & Mainly HI-LT & $\begin{array}{l}\text { Mainly LO-ST (even if some of } \\
\text { them can be durable LO) }\end{array}$ \\
\hline$\underline{\text { Fabi }}$ & Mainly HI-ST & Mainly HI-LT & $\begin{array}{l}\text { Mainly LO-ST (some of them } \\
\text { can be durable LO) }\end{array}$ \\
\hline$\underline{\text { Cesare Paciotti }}$ & Mainly HI-ST & Mainly HI-LT & Mainly LO-ST \\
\hline$\underline{\text { Suppliers' view }}$ & $\begin{array}{l}\text { Mainly HI-ST } \\
\text { [e.g. Conceria del Chienti] }\end{array}$ & $\begin{array}{l}\text { Mainly HI-LT } \\
\text { [e.g. Finproject] }\end{array}$ & $\begin{array}{l}\text { Mainly LO-ST (mainly durable) } \\
\text { [e.g. Conceria Tirrena] }\end{array}$ \\
\hline
\end{tabular}


Table 8: Characteristics of ASPs developed with external leather suppliers

\begin{tabular}{|c|c|c|c|}
\hline Characteristic & Manas & Fabi & Cesare Paciotti \\
\hline $\begin{array}{l}\text { Part of a portfolio } \\
\text { of supply } \\
\text { partnerships }\end{array}$ & $\begin{array}{l}\text { Short-term partnerships are complemented by long-term } \\
\text { partnership given that established suppliers are considered } \\
\text { key for the fast ramp-up of the production process and, } \\
\text { whenever possible, the company prefers not to close down } \\
\text { suddenly any supply relationship. }\end{array}$ & $\begin{array}{l}\text { Fabi has built a very wide portfolio of external leather } \\
\text { suppliers (almost 150) and each season chooses the best } \\
\text { fitting suppliers on the basis of the fashion trend and on the } \\
\text { collection's desired look. Some of these suppliers are } \\
\text { selected every season and become long-term partners. }\end{array}$ & $\begin{array}{l}\text { The approach to supply partnerships is balancing two } \\
\text { different pressures: the need for renewal vs. the importance } \\
\text { of continuity in relationships. This is because over time the } \\
\text { company and its suppliers get to know each other better } \\
\text { and better. }\end{array}$ \\
\hline $\begin{array}{l}\text { Project based } \\
\text { features }\end{array}$ & $\begin{array}{l}\text { In each fashion season key external leather suppliers are } \\
\text { involved in the development of the new models, treating } \\
\text { each collection as a project. These suppliers gain the } \\
\text { majority of the orders, but the company's policy is to } \\
\text { always have a second sourcing alternative for key } \\
\text { materials. }\end{array}$ & $\begin{array}{l}\text { Suppliers are selected with respect to a specific project (a } \\
\text { product range within one fashion season) due to the high- } \\
\text { end market positioning of the company and the need to be } \\
\text { at the forefront of fashion. }\end{array}$ & $\begin{array}{l}\text { Emphasis is placed on the relevance of external leather } \\
\text { because of its impact on the look of the shoes. Every } \\
\text { season the company radically revises the choice of the } \\
\text { external leather suppliers and relationships are developed } \\
\text { for a single season. Supply contracts are signed season by } \\
\text { season, based on actual orders. }\end{array}$ \\
\hline $\begin{array}{l}\text { Pre-qualified } \\
\text { supplier base }\end{array}$ & $\begin{array}{l}\text { Specialist subcontractors have critical know-how for the } \\
\text { final look of the shoes and they rely on their competence. } \\
\text { This relationship can be short-term, given the changes in } \\
\text { fashion trends. } \\
\text { The company has developed a network with many } \\
\text { suppliers, keeping track of their capabilities and } \\
\text { performance. Moreover, they regularly look for new } \\
\text { external leather suppliers. }\end{array}$ & $\begin{array}{l}\text { The continuous search for new ideas to renew the } \\
\text { collection requires innovative suppliers that can respond } \\
\text { and shape fashion trends. } \\
\text { To balance stability and innovation, a large network of } \\
\text { relationships has been built. A database is used to select } \\
\text { suppliers every season based on a match between } \\
\text { capabilities and fashion trends. Relationships with } \\
\text { tanneries in other Italian districts allow identification of } \\
\text { potentially new suppliers. }\end{array}$ & $\begin{array}{l}\text { The company recognizes that the strength in the } \\
\text { development of fashionable shoes is based not only on its } \\
\text { own creativity but also on the contribution of a network of } \\
\text { suppliers, predominantly those supplying external leather. } \\
\text { Local suppliers represent a large supplier base and, within } \\
\text { the district, the pre-qualification is often simplified by the } \\
\text { reputation of the supplier. }\end{array}$ \\
\hline Intermittence & $\begin{array}{l}\text { There are "sleeping" supply relationships that can be } \\
\text { reactivated quickly in case the fashion trend is asking again } \\
\text { for a particular type of material or a specific material } \\
\text { processing. }\end{array}$ & $\begin{array}{l}\text { Continuous monitoring of the supplier capabilities and } \\
\text { performance, to be able to involve suppliers when required. }\end{array}$ & $\begin{array}{l}\text { Building relationships, even if intermittent, is considered } \\
\text { important. Such experience can help to face the many } \\
\text { predicaments that characterize fashion seasons both in the } \\
\text { development of the collection and during } \\
\text { production/delivery. } \\
\text { Shared experiences with suppliers are critical to reduce the } \\
\text { lead-times in product development and production. }\end{array}$ \\
\hline
\end{tabular}

